\title{
BRAF NP_004324.2:p.V600M
}

National Cancer Institute

\section{Source}

National Cancer Institute. BRAFNP 004324.2:p.V600M. NCI Thesaurus. Code C98351.

A change in the amino acid residue at position 600 in the serine/threonine protein kinase

B-raf protein where valine has been replaced by methionine. 